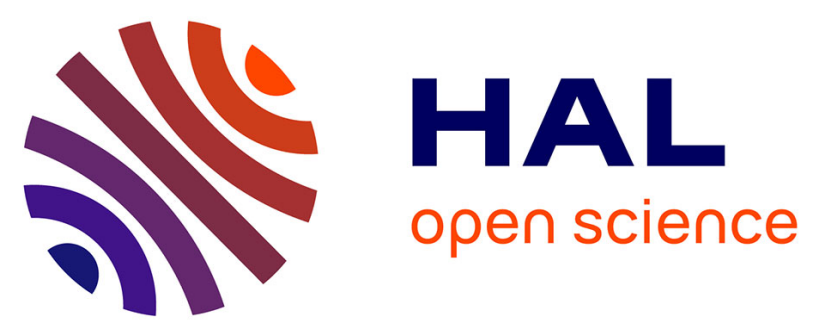

\title{
Microstructural and mechanical properties evolutions of plasma transferred arc deposited Norem02 hardfacing alloy at high temperature
}

Gauthier Beaurin, Jean-Philippe Mathieu, Elise Gauthier, Daniel Nelias, Michel Coret, Felix Arnoldi

\section{To cite this version:}

Gauthier Beaurin, Jean-Philippe Mathieu, Elise Gauthier, Daniel Nelias, Michel Coret, et al.. Microstructural and mechanical properties evolutions of plasma transferred arc deposited Norem02 hardfacing alloy at high temperature. Materials Science and Engineering: A, 2011, 528 (15), pp.5096 5105. 10.1016/j.msea.2011.02.077 . hal-01007047

\section{HAL Id: hal-01007047 \\ https://hal.science/hal-01007047}

Submitted on 18 Jan 2017

HAL is a multi-disciplinary open access archive for the deposit and dissemination of scientific research documents, whether they are published or not. The documents may come from teaching and research institutions in France or abroad, or from public or private research centers.
L'archive ouverte pluridisciplinaire HAL, est destinée au dépôt et à la diffusion de documents scientifiques de niveau recherche, publiés ou non, émanant des établissements d'enseignement et de recherche français ou étrangers, des laboratoires publics ou privés. 


\title{
Microstructural and mechanical properties evolutions of plasma transferred arc deposited Norem02 hardfacing alloy at high temperature
}

\author{
Gauthier Beaurin ${ }^{\mathrm{a}, \mathrm{b}}$, Jean-Philippe Mathieu ${ }^{\mathrm{a}}$, Elise Gauthier ${ }^{\mathrm{a}}$, Daniel Nelias ${ }^{\mathrm{b}}$, \\ Michel Coret ${ }^{\mathrm{b}}$, Felix Arnoldi ${ }^{\mathrm{a}}$ \\ a EDF REDD, Département MMC, 24 rue Carnot, Bât. C24, 77818 Moret-sur-Loing Cedex, France \\ b INSA-Lyon, LaMCoS, CNRS UMR5259, F-69621, France
}

\begin{abstract}
Plasma-transferred-arc welded Norem02, an iron-based hard-facing alloy, was characterised. Its microstructure and chemical composition were investigated using optical microscopy, scanning electron microscopy (with electron probe microanalysis), electron backscattering diffraction, and X-ray diffraction. The microstructure of the as-deposit alloy consists of a dendritic austenite structure with ferrite islets at dendrites centres, with an interdendritic eutectic region containing austenite, $\mathrm{M}_{7} \mathrm{C}_{3}$ and $\mathrm{M}_{23} \mathrm{C}_{6}$ carbides and zones containing Mo-rich precipitates. Tensile behaviour of Norem02 was characterised and completed by dilatometry tests in welding process temperature range. No significant phase transformation was detectable during mechanical testing. Different heat treatment cycles of ageing at high temperatures (until $1100^{\circ} \mathrm{C}$ ) were carried out for different durations. The microstructure of Norem02 heated at $1100^{\circ} \mathrm{C}$ was not significantly affected by a short time (15s) treatment whereas changes were observed for longer durations $(2 \mathrm{~h}$ ), although hardness remains almost unchanged.

This work tends to demonstrate that for this alloy metallurgical evolution during the welding process has very little influence on mechanical properties.
\end{abstract}

Keywords: Mechanical properties, Welding, High temperature, Microstructure

\section{Introduction}

Hardfacing alloys coatings are often used on the surfaces of parts subjected to drastic loadings. Stellite Co-based alloys offer good properties moreover when associated with innovative deposition technique [1] and were traditionally widely used as a hardfacing alloy into nuclear power plants especially on valves seating surfaces.

However, in the primary coolant circuit, ${ }^{59} \mathrm{Co}$, stable, produces very radioactive ${ }^{60} \mathrm{Co}$ by radiative capture of neutrons following the transmutation reaction: ${ }_{27}^{59} \mathrm{Co}+{ }_{0}^{1} n \rightarrow{ }_{27}^{60} \mathrm{Co}+\gamma$. Measurements show that the gamma-emitting isotope ${ }^{60} \mathrm{Co}$ is the largest contributor to personnel exposure [2] and valve maintenance is known as an important one.

To lower the radiation level resulting in hazards associated with the maintenance of components [3], cobalt-free hardfacing alloys have been tested. Among these, Norem02, a Fe-based alloy, is of particular interest due to its good fracture-toughness and galling wear resistance [4]. Deposited by Plasma Transferred Arc Welding (PTAW) process on a 316L stainless steel substrate, it leads to a sound metallurgical bond, and its mechanical properties are quite equivalent to those of Stellite [5].
This work aims at considering material-related difficulties for simulation of welding of Norem02 by finite element modelling, in order to evaluate residual stress influence on thermal shock toughness [6]. Metallurgical state can contribute substantially to mechanical behaviour and by extension to residual stress state after welding $[7,8]$. That is why this article focuses on metallurgy evolution and on mechanical properties in PTAW process range of temperature.

Facing the lack of metallurgical knowledge about Norem02 phase transformations in literature, it is also attempted in this work to propose an analysis of phase repartition of the as-deposited material, and to characterize its evolution during a post-welding thermal process reproducing thermal state of Norem02 during welding cooling/reheating phases.

\section{Experimental procedures}

\subsection{Specimens}

Norem02 coatings were deposited on a $316 \mathrm{~L}$ stainless steel substrate by PTAW (see Fig. 1). The deposit was several times thicker than those on real valves so that test specimens could be 

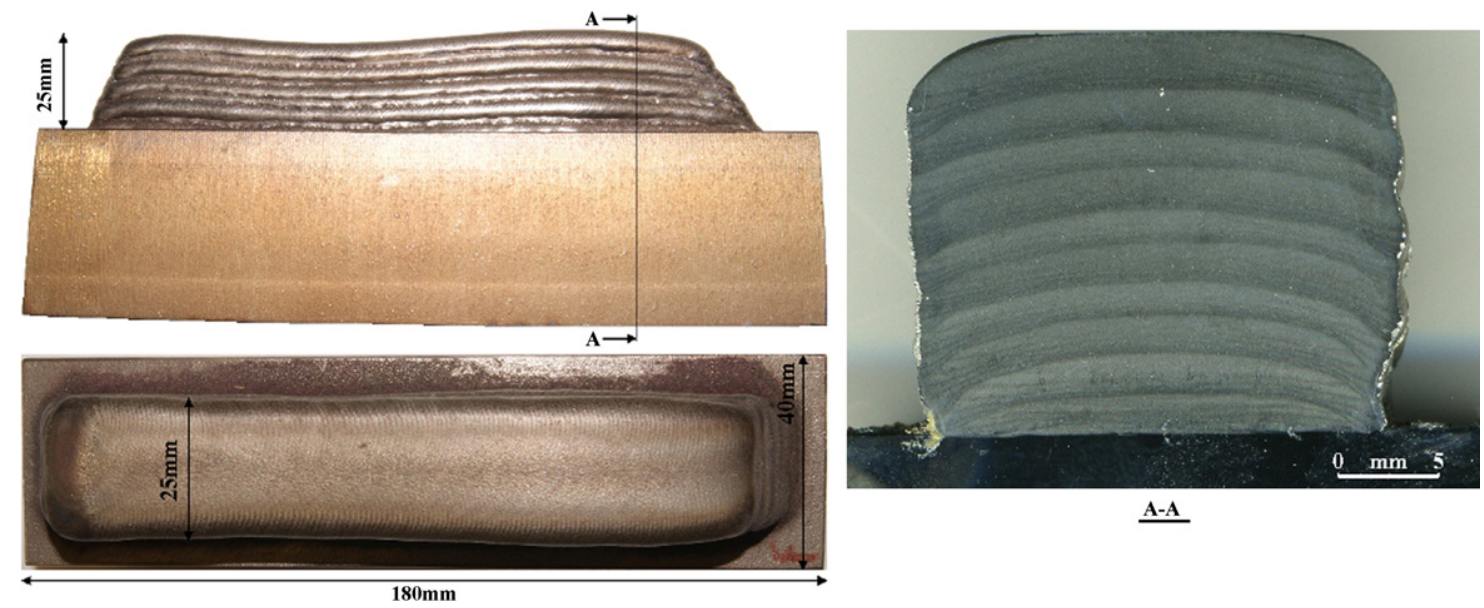

Fig. 1. Multi-layer Norem02 PTAW deposit on 316L stainless steel substrate.

Table 1

Welding parameters used in PTAW process.

\begin{tabular}{|c|c|}
\hline Numbers of layers & 10 \\
\hline Preheat temperature & $100_{0}^{+50}{ }^{\circ} \mathrm{C}$ \\
\hline Inter-pass heat temperature & $100_{0}^{+50}{ }^{\circ} \mathrm{C}$ \\
\hline Medium of cooling & Vermiculate powder \\
\hline 1st layer current & $120 \mathrm{~A}$ \\
\hline Other layers current & $90 \mathrm{~A}$ \\
\hline Voltage & $33.5 \mathrm{~V}$ \\
\hline Travel speed & $35_{-5}^{+5} \mathrm{~mm} \mathrm{~min}^{-1}$ \\
\hline Plasma gas & Argon \\
\hline Plasma gas flow rate & $1.6 \mathrm{Lmin}^{-1}$ \\
\hline Shielding gas & Argon $+5 \%$ hydrogen \\
\hline Shielding gas flow rate & $80 \mathrm{Lmin}^{-1}$ \\
\hline Powder gas & Argon $+5 \%$ hydrogen \\
\hline Powder gas flow rate & $10 \mathrm{Lmin}^{-1}$ \\
\hline Powder feed rate & $35 \mathrm{~g} \mathrm{~min}^{-1}$ \\
\hline Tungsten electrode diameter & $4 \mathrm{~mm}$ \\
\hline
\end{tabular}

machined within the coating. The thickness of the deposition layer was approximately $25 \mathrm{~mm}$, as shown in Fig. 1. The concentrated heat pattern of high temperature arc in the chosen welding process limits heat transfer to base metal and accelerates molten pool solidification with minimum dilution, leading to a very small heat affected zone (HAZ).

PTAW process welding parameters are given in Table 1 . The chemical composition of Norem02 powder used for PTAW is given in Table 2.

Cylindrical specimens were cut using wire-cut electrical discharge machining, and then machined in order to meet geometries shown in Fig. 2. Moderate temperature $\left(<600^{\circ} \mathrm{C}\right)$ tension tests specimens are shown in Fig. 2a. Dilatometry tests, high temperature tension tests and heat treatment test specimens were identical (see Fig. 2b). Both were then mechanically polished and ultrasonically cleaned to eliminate the work-hardened layer. Tension-compression test specimens (see geometry in Fig. 2c) were designed in order to avoid buckling. Dutheil critical load is defined for our specimen shape as [9]:

$\sigma_{\mathrm{t}}=\sigma_{\mathrm{c}}+1.3 \sigma_{\mathrm{e}}$

Table 2

Chemical composition of Norem02 powder.

\begin{tabular}{cllllllllll}
\hline & $\mathrm{C}$ & $\mathrm{Mn}$ & $\mathrm{Cr}$ & $\mathrm{Si}$ & $\mathrm{Ni}$ & $\mathrm{Mo}$ & $\mathrm{N}_{2}$ & $\mathrm{Co}$ & $\mathrm{B}$ & $\mathrm{Fe}$ \\
\hline $\begin{array}{c}\text { Composition } \\
\text { (wt. \%) }\end{array}$ & 1.23 & 4.3 & 25.4 & 3.38 & 4.0 & 2.0 & 0.17 & 0.01 & $\leq 0.001$ & Bal \\
\hline
\end{tabular}

$$
\begin{aligned}
& F=\frac{\pi D^{2}}{4\left(\sigma_{\mathrm{t}} / 2-\sqrt{\sigma_{\mathrm{t}}^{2} / 4-\sigma_{\mathrm{e}} \sigma_{\mathrm{c}}}\right)} \\
& \lambda_{\mathrm{c}}^{2}=\pi^{2} \frac{E}{\sigma_{\mathrm{e}}}
\end{aligned}
$$

where $\sigma_{\mathrm{t}}$ is the practical compression load, $\sigma_{\mathrm{e}}$ is the yield strength, $\sigma_{\mathrm{c}}$ is the Euler critical load. $L$ being the specimen unsupported length, and $\lambda_{c}$ the critical slenderness coefficient defined by the material parameters (for Norem02, $\lambda_{\mathrm{c}}=51.1$ at $20^{\circ} \mathrm{C}$ according to Eq. (3)).

It is worth noting that sampling avoided the first and second deposited layer as well as the last one, in order to avoid specific composition and/or metallurgical state.

\subsection{As-deposit microstructure characterization}

Characterization of the as-deposit Norem02 microstructure has been carried out in order to determine phase distribution and composition. Specimens were in a first time sectioned and polished using standard metallographic procedures. Samples were then chemically etched using successively a $\mathrm{NaOH}$ solution at $1.7 \mathrm{~V}$ during $30 \mathrm{~s}$ and an oxalic acid solution at $1.7 \mathrm{~V}$ for approximately 2 min to reveal the base metal microstructure.

Optical microscopy and scanning electron microscopy (SEM) were then carried out on cross-sections perpendicular to the welding direction to examine the microstructure, e.g., the type, shape, size and distribution of carbides, the size and distribution of ferrite and austenite.

X-ray diffraction (XRD) analysis series were made with a Rigaku Geigerflex diffractometer equipped with a Siemens KFN Co2L diffraction tube running at $30 \mathrm{kV}$ and $37.5 \mathrm{~mA}$, an incident beam monochromator and a scintillation counter. Experiments were performed by placing the $8 \mathrm{~mm}^{2}$ area and 3-4 mm thick samples on a flat sample holder.

\subsection{High temperature state microstructure characterization}

Microstructures have been characterized after heat treatment at $1100^{\circ} \mathrm{C}$. These treatments were performed using a Gleeble 3500 heating through Joule effect machine. Four thermocouples percussion-welded to the outer surface of the samples, at the centre and at $5 \mathrm{~mm}, 10 \mathrm{~mm}$, and $15 \mathrm{~mm}$ far from the middle (see Fig. 2b), provided local temperature readings and control during heating and cooling.

Hydraulic servo system was used to hold down the specimen maintaining tension around 0 , and a $7 \mathrm{kN}$ load cell was record- 
(a)

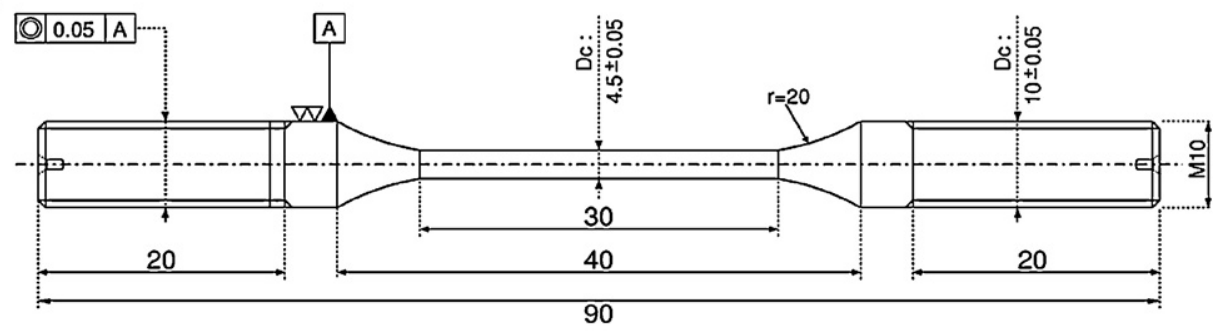

(b)

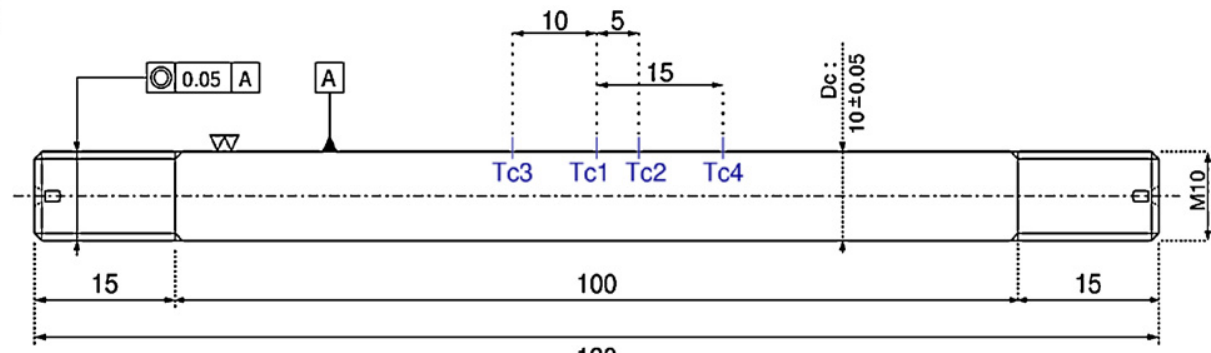

130

(c)

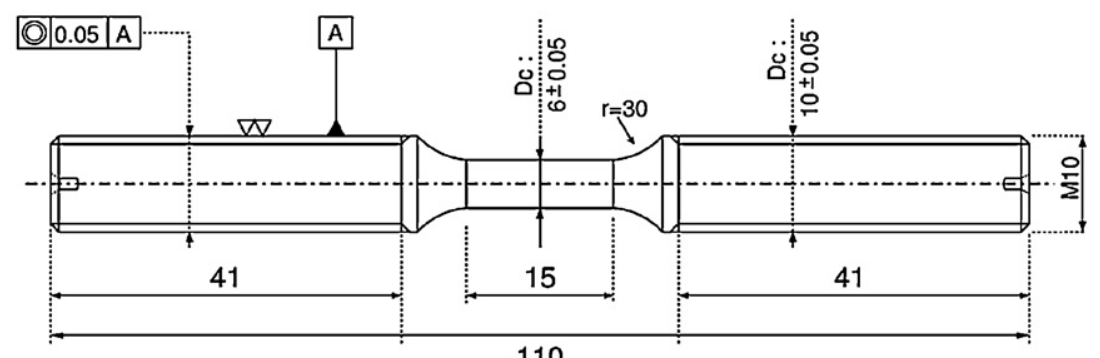

110

Fig. 2. Specimen geometries for: (a): low temperature tension tests $\left(<600^{\circ} \mathrm{C}\right)$, (b): high temperature tension tests $\left(\geq 600^{\circ} \mathrm{C}\right)$, and $(\mathrm{c})$ : tension-compression test.

ing the force. Heating rate was low in order to limit the thermal gradient in the specimen thickness and plastic deformations. Cooling was achieved by an automatically controlled high pressure water jet. The tests were performed using Gleeble copper jaws to enable fast quenching in order to avoid non-martensitic phase transformation.

Heat treatment cycles carried out are shown in Fig. 3. After heating at a specified temperature $T_{\mathrm{ann}}$, specimens were kept at $T_{\mathrm{ann}}$ for several durations, and then water quenched to room temperature at maximal cooling rate to overtake critical quenching rate. Holding time, stabilized temperature, heating and estimated quenching rates are presented in Table 3.

Sample metallurgical analyses were then performed using analogue procedures to those employed at as-deposit state.

\subsection{Vickers hardness measurements}

Vickers hardness profiles were obtained along a cross line with a load of $10 \mathrm{~kg}$ on sample R1100_LONG. To access the evolution of hardness with increasing of isothermal temperature reached before cooling, hardness measurement were performed along a $45 \mathrm{~mm}$ long cross line, in deposit way.

\subsection{Dilatometry tests}

The Gleeble machine was used to perform dilatometry tests. 316L stainless steel jaws were used to minimize thermal gradient. Mechanical loading was continuously around $0 \mathrm{~N}( \pm 5 \mathrm{~N})$. Force was recorded using a $7 \mathrm{kN}$ cell. In this manner, only the temperature

Table 3

Annealing tests measurements.

\begin{tabular}{|c|c|c|c|c|}
\hline Axial position & Peak temp $\left({ }^{\circ} \mathrm{C}\right)$ & Isothermal temp $\left({ }^{\circ} \mathrm{C}\right)$ & Heating rate $\left({ }^{\circ} \mathrm{Cs}^{-1}\right)$ & Estimated cooling rate $\left({ }^{\circ} \mathrm{Cs}^{-1}\right)$ \\
\hline \multicolumn{5}{|c|}{ Heating time $15 \mathrm{~s}-\mathrm{R} 1100 \_S H O R T$} \\
\hline Centre & 1109.1 & 1100.0 & 109 & 10,512 \\
\hline $5 \mathrm{~mm}$ & 1086.0 & 1045.2 & 107 & 5365 \\
\hline $10 \mathrm{~mm}$ & 1078.7 & 995.8 & 106 & 2351 \\
\hline $15 \mathrm{~mm}$ & 960.8 & 792.2 & 94 & 1691 \\
\hline \multicolumn{5}{|c|}{ Heating time $2 \mathrm{~h}-\mathrm{R} 1100 \_$LONG } \\
\hline Centre & 1109.3 & 1100.0 & 109 & 7809 \\
\hline $5 \mathrm{~mm}$ & 1011.6 & 1061.9 & 99 & 3521 \\
\hline $10 \mathrm{~mm}$ & 1068.9 & 991.1 & 105 & 1116 \\
\hline $15 \mathrm{~mm}$ & 979.2 & 938.9 & 96 & 294 \\
\hline
\end{tabular}



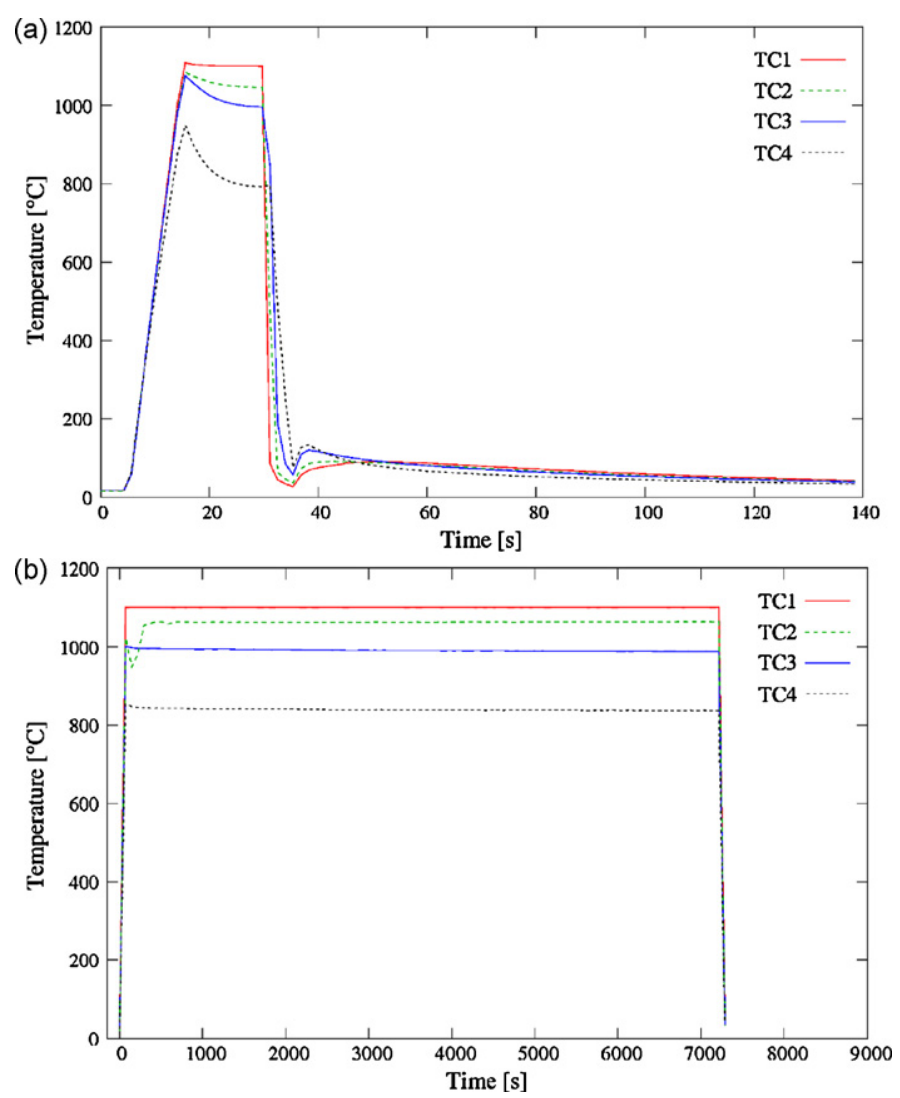

Fig. 3. Thermal loading used for the study of the influence of the reached temperature - (a) R1100_SHORT and (b) R1100_LONG.

variation is responsible for measured displacements. The direct resistance heating system heats specimens up to $1000^{\circ} \mathrm{C}$ at a rate of $20^{\circ} \mathrm{C} \mathrm{s}^{-1}$, low enough to ensure an almost uniform temperature within the gauge length. Samples were then air-cooled until room temperature (stabilized at $20^{\circ} \mathrm{C}$ during the test) at a decreasing rate ranging from $30^{\circ} \mathrm{Cs}^{-1}$ at the beginning of cooling phase to

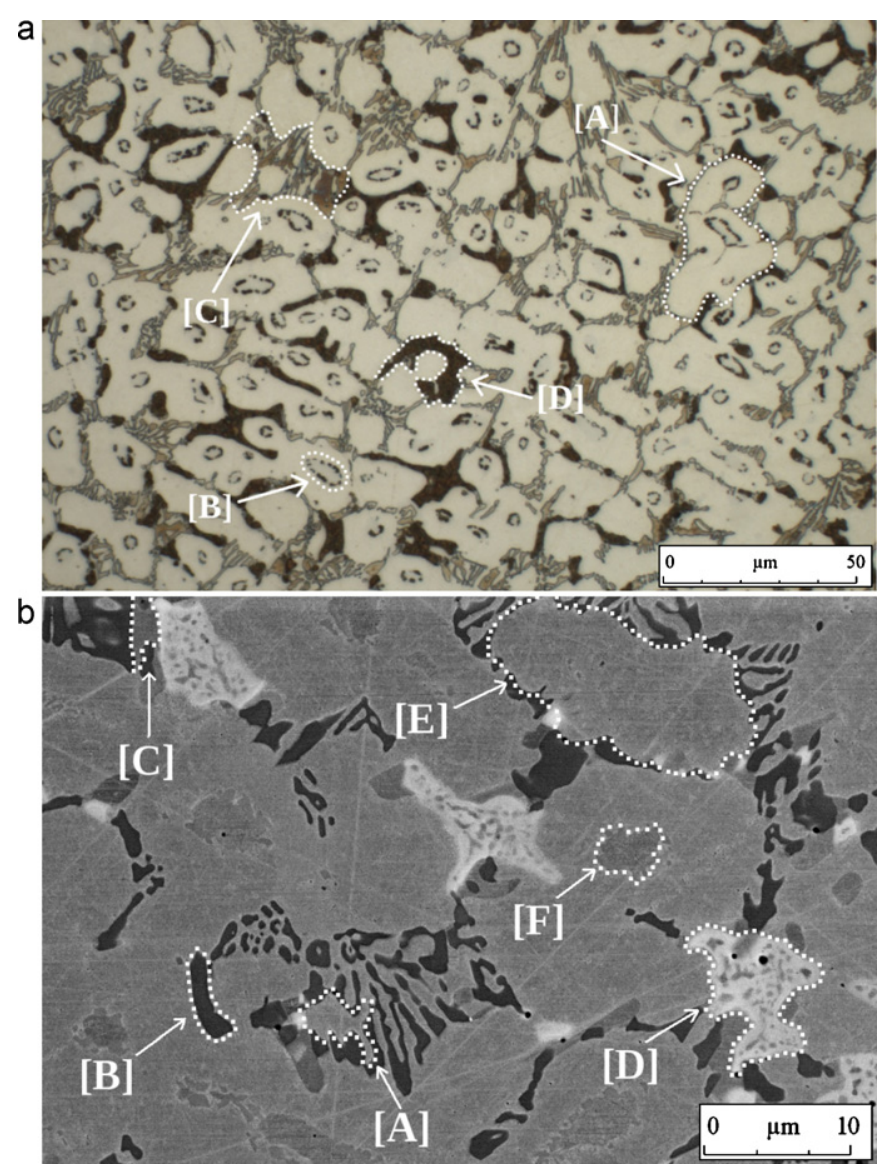

Fig. 4. Norem02 as-deposit microstructure - (a) optical microscopy and (b) SEM.

$0{ }^{\circ} \mathrm{Cs}^{-1}$ at the end. To measure expansion of the specimen, elongation was recorded within the gauge length using HZT-071 axial extensometer which gauge length was exactly $10 \mathrm{~mm}$ at test start, and the current diameter of the gauge region was recorded using a dilatometer.
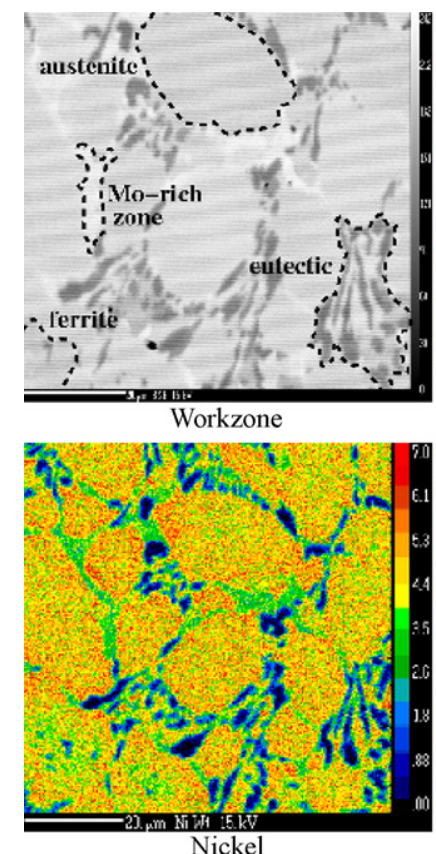

Nickel
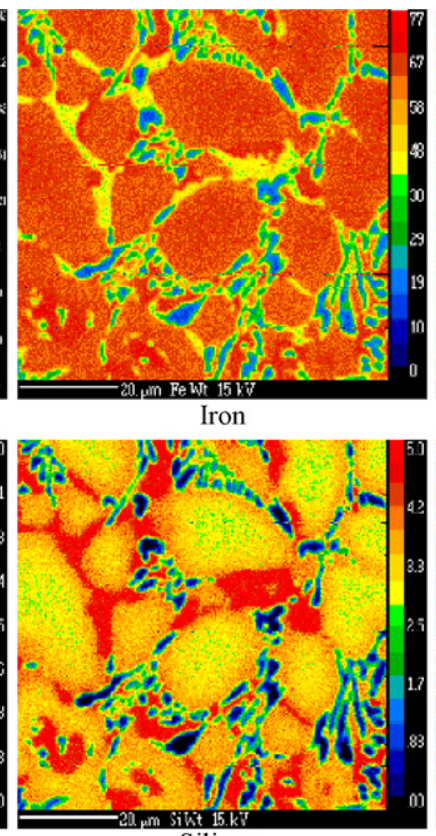

Silicon

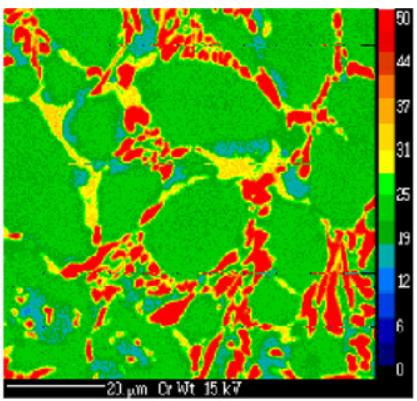

Chromium

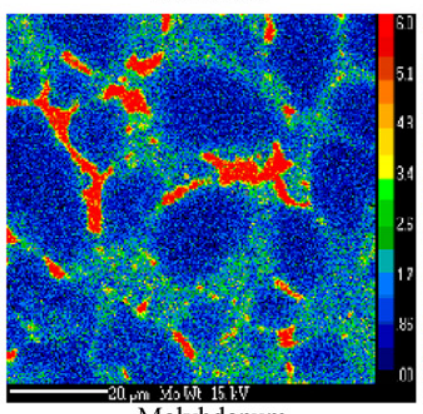

Molybdenum
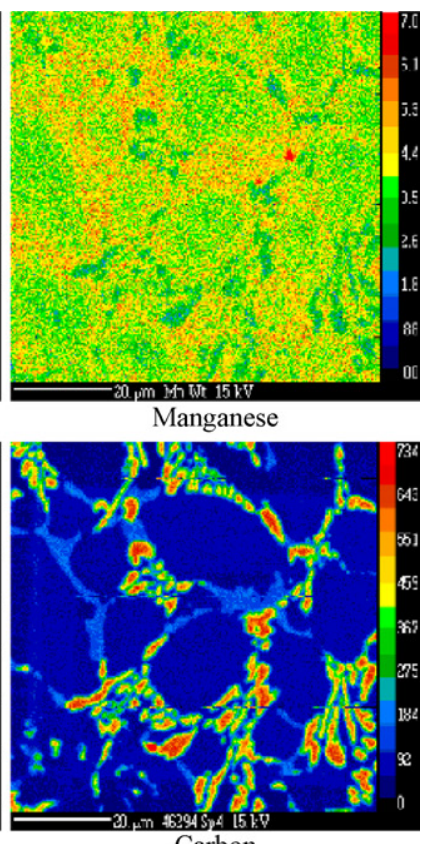

Carbon

Fig. 5. As-deposit Norem02 - electron probe microprobe scanning compositional map. 


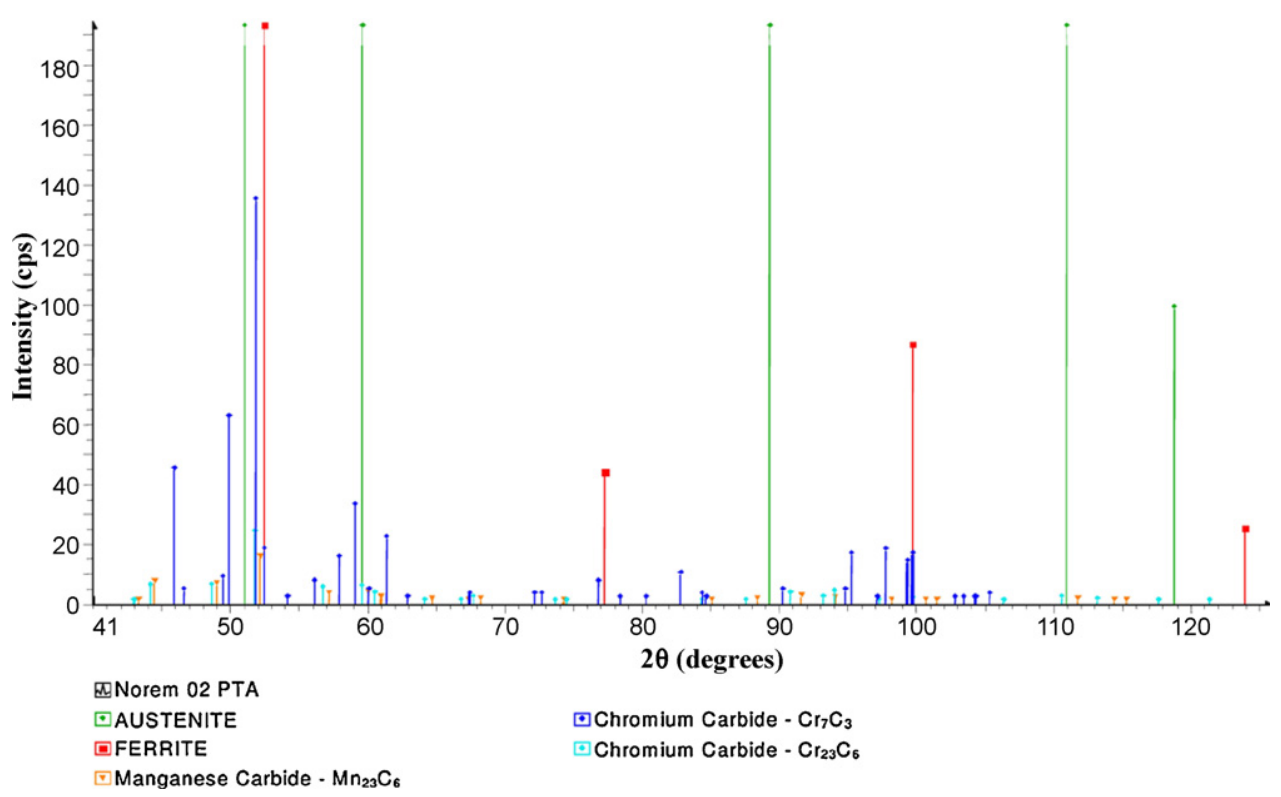

Fig. 6. As-deposit Norem $02 \mathrm{X}$-ray diffraction pattern.

\subsection{Tensile tests}

Tensile tests were performed using the Gleeble machine and a $22 \mathrm{kN}$ load cell. During each test, room temperature was maintained constant to $20^{\circ} \mathrm{C}$. Heating rate was $10^{\circ} \mathrm{Cs}^{-1}$ since the specified temperature was reached. A constant temperature was maintained during $10 \mathrm{~min}$ according to [10] to ensure its stabilization. Zero tension load was maintained during heating process allowing thermal expansion. The tensile test load was then applied until failure. Imposed strain rate was $10^{-4} \mathrm{~s}^{-1}$.

Strain was measured using an HZT-071 axial extensometer adequate for high temperature testing. Gauge length of the extensometer was $10 \mathrm{~mm}$, linearity was $\pm 0.15 \%$. Temperature variation within the specimen gauge length was kept less than $6^{\circ} \mathrm{C}$ during the tests.

\subsection{Tension-compression tests}

Tension-compression test was performed using the same load cell, at room temperature. Imposed strain rate was $10^{-4} \mathrm{~s}^{-1}$. Cyclic loading started in the tension way, from a zero-value of the tension-compression couple. Five tension-compression cycles were performed for each strain level in order to determine the number of cycles influence. Strain level was $+0.4 \%$ in tension and $-0.4 \%$ in compression at early test, and then increased by $0.2 \%$ steps until failure.

\section{Results}

\subsection{As-deposit microstructure characterization}

One can see in Fig. 4a fine and complex microstructure. Asdeposit PTAW Norem02 is constituted with austenitic dendrites from 10 to $30 \mu \mathrm{m}$ [A - Fig. 4a] with ferrite islets in their centre [B - Fig. 4a]. Interdendritic zone is characterized as an eutectic composed by $\mathrm{M}_{7} \mathrm{C}_{3}$ carbides [C - Fig. 4a] and other phases [D Fig. 4a], appearing in darker in optical microscopy although white in SEM. These observations are consistent with those exposed in Cockeram's previous works [2], as well as in a characterization led in EDF [11].
Chemical composition of each phase was determined using an electron probe micro-analyser in [A-F - Fig. 4b] annotated areas. Table 4 shows average compositions. Cartographies were also made and are shown in Fig. 5. Interdendritic zone is constituted with austenite [A - Fig. 4b], carbides $\mathrm{M}_{7} \mathrm{C}_{3}$ [B - Fig. 4b], ferrite [C Fig. 4b], and white precipitates [D - Fig. 4b].

Electron probe micro-analysis in interdendrite [E - Fig. 4b] and inside the dendrites [F - Fig. 4b] allows us to distinguish two types of ferrite, differing mainly by their $\mathrm{Cr}$ rate. In fact, $\mathrm{Cr}$ rate is high in austenitic phase. Mo rich white precipitates zones are probably constituted with $\mathrm{M}_{23} \mathrm{C}_{6}$ carbides since $\mathrm{C}$ rate appears lower than in other $\mathrm{M}_{7} \mathrm{C}_{3}$ carbides zones.

Radiocrystallography phase analysis on an as-deposit Norem02 sample illustrated in Fig. 6 confirms previous observations. Moreover, it is consistent with previous analysis on Norem02 alloys [2,11], since eutectic carbides $\mathrm{M}_{7} \mathrm{C}_{3}$ and non-eutectic carbides $\mathrm{M}_{23} \mathrm{C}_{6}$ are present. The latter are observed in smaller proportions, since we hardly distinguish them from the background noise. $\mathrm{X}$ ray diffraction pattern contains the peaks of austenite, which is the

Table 4

As-deposit Norem02 microprobe analysis - average phases composition (wt.\%).

\begin{tabular}{llllllll}
\hline & $\mathrm{C}$ & $\mathrm{Mn}$ & $\mathrm{Cr}$ & $\mathrm{Si}$ & $\mathrm{Ni}$ & $\mathrm{Mo}$ & $\mathrm{Fe}$ \\
\hline Austenite [A and E - Fig. 4b] & & 3.8 & 22.2 & 3.4 & 4.5 & 1.0 & 65.1 \\
Intradendritic ferrite [F - Fig. 4b] & & 3.2 & 17.2 & 4.8 & 3.6 & 1.0 & 70.1 \\
Interdendritic ferrite [C - Fig. 4b] & & 4.2 & 18.6 & 4.7 & 4.2 & 1.8 & 66.5 \\
Carbides [B - Fig. 4b] & 9.4 & 2.4 & 66.1 & 0 & 0.4 & 2.0 & 19.6 \\
White precipitates [D - Fig. 4b] & & 4.6 & 31.0 & 4.9 & 3.0 & 7.7 & 48.8
\end{tabular}

Table 5

Material properties of Norem02.

\begin{tabular}{clll}
\hline $\begin{array}{l}\text { Temperature } \\
\left({ }^{\circ} \mathrm{C}\right)\end{array}$ & $\begin{array}{l}\text { Elastic modulus, } E \\
(\mathrm{GPa})\end{array}$ & $\begin{array}{l}0.2 \% \text { yield strength } \\
(\mathrm{MPa})\end{array}$ & $\begin{array}{l}\text { Ultimate } \\
\text { strength }(\mathrm{MPa})\end{array}$ \\
\hline 20 & 187 & 621 & 867 \\
200 & 170 & 448 & 699 \\
400 & 168 & 421 & 675 \\
600 & 151 & 384 & 589 \\
700 & 107 & 268 & 372 \\
800 & 94 & 195 & 230 \\
1000 & 59 & 31 & 48 \\
\hline
\end{tabular}



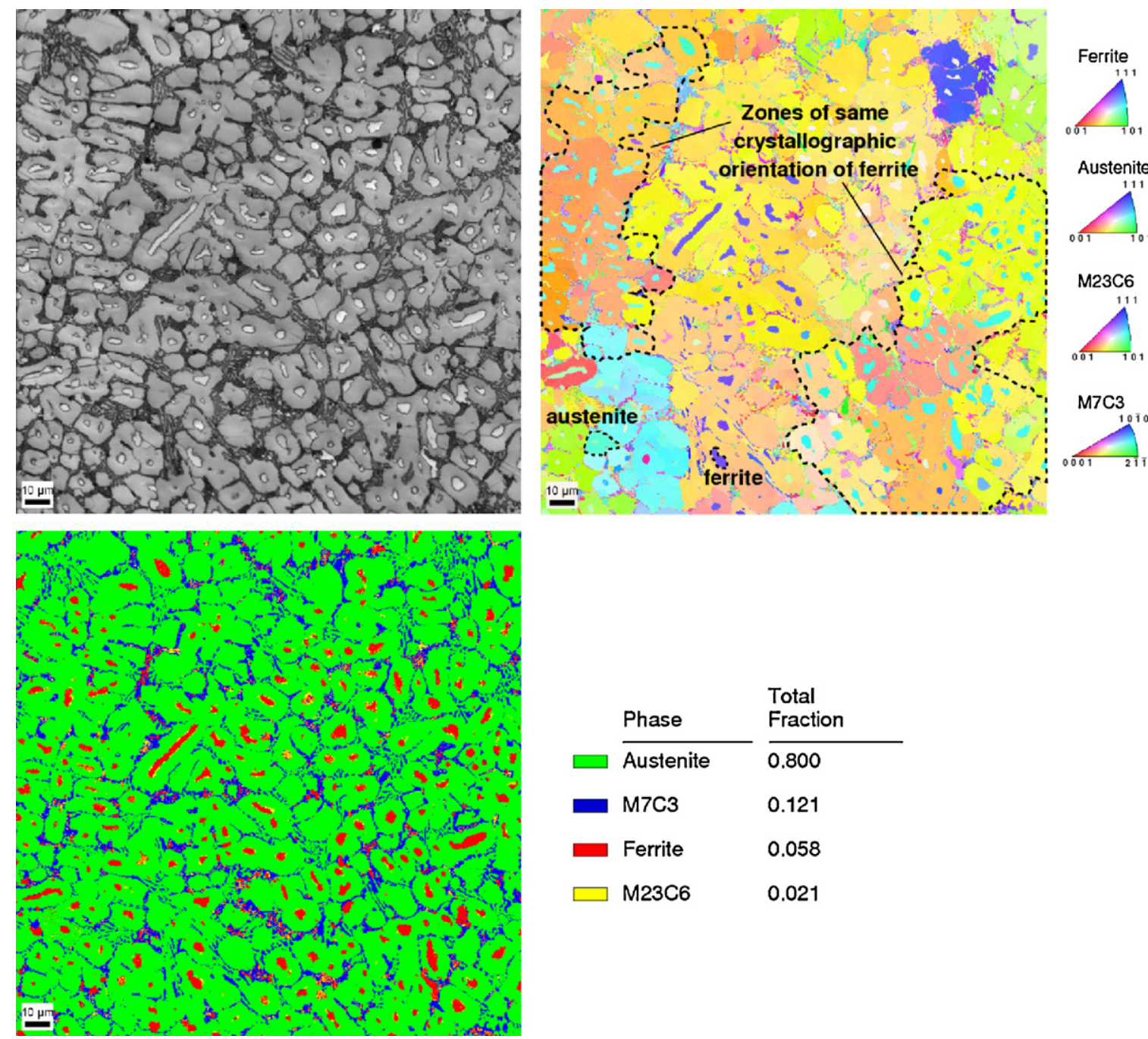

\begin{tabular}{ll} 
Phase & $\begin{array}{l}\text { Total } \\
\text { Fraction }\end{array}$ \\
\cline { 1 - 1 } Austenite & 0.800 \\
M7C3 & 0.121 \\
Ferrite & 0.058 \\
M23C6 & 0.021
\end{tabular}

Fig. 7. As-deposit Norem02 EBSD orientation maps.

major constituent, ferrite and $M_{7} C_{3}$ chromium, while the $M_{23} C_{6}$ carbides peaks are clearly smaller.

Electron back-scattering diffraction (EBSD) was also used to characterize the microstructure crystallographic orientations repartition. Orientation maps obtained are shown in Fig. 7.

Austenitic dendrite microstructure shows relatively small dendrite size (around $100 \mu \mathrm{m}$ for packets of same orientation). The observed area is quite representative of the observed microstructure in the whole deposit.

One can also observe several distinct austenitic areas with a same crystallographic orientation of ferrite. It could be interpreted as a proof that the growth of the austenite is not random, but rather that there is a germination of austenite variants on ferrite during cooling phase. This would be consistent with Cockeram's observations [2] reporting that this ferrite is $\delta$-ferrite, formed by fast cooling from high temperature during welding process.

\subsection{High temperature state microstructure characterization}

One can see in Fig. 8 optical microscopy and SEM observations of R1100_SHORT sample, heated at $1100^{\circ} \mathrm{C}$ during $15 \mathrm{~s}$. Comparing these observations to those in Fig. 4 obtained from as-deposit material, one can see that white precipitate zone [A - Fig. 8a] are slightly bigger than in untreated state. Ferrite skeleton morphology inside austenite dendrites [B - Fig. 8a] is less apparent. Interden- dritic zone composition has not changed although $\mathrm{M}_{7} \mathrm{C}_{3}$ carbides in eutectic [C - Fig. 8a] appeared smaller.

According to electron probe microanalysis, carbides composition [A - Fig. 8b] was unchanged, as seen in Table 6 . The volume fraction of the white zones precipitates [B - Fig. $8 \mathrm{~b}$ ] is lower, and there is a drop of the Mo rate. A new dark region appears, $\mathrm{Cr}$-rich according to microprobe analysis. It consists of new carbides, different from $\mathrm{M}_{3} \mathrm{C}_{7} . \mathrm{Cr}$ and Mo rates in intradendritic ferrite increase. Austenitic matrix composition was unchanged.

The structure of deposits was then characterized after $2 \mathrm{~h}$ heating at $1100^{\circ} \mathrm{C}$. Optical microscopy and SEM observations are shown in Fig. 9 and exhibit drastic changes in microstructure. Austenitic matrix composition, obtained with electron microprobe and given in Table 7, is similar to R1100_SHORT sample austenitic matrix composition. One can only see a slight rise in Si rate. Ferrite islets inside dendrites totally disappeared so that no trace of ferrite remained.

Table 6

R1100_SHORT sample microprobe analysis - average phases composition (wt.\%).

\begin{tabular}{llllllll}
\hline & $\mathrm{C}$ & $\mathrm{Mn}$ & $\mathrm{Cr}$ & $\mathrm{Si}$ & $\mathrm{Ni}$ & $\mathrm{Mo}$ & $\mathrm{Fe}$ \\
\hline Austenite & & 4.0 & 21.9 & 3.7 & 4.7 & 0.9 & 66.2 \\
Intradendritic ferrite & & 3.2 & 23.2 & 4.8 & 3.3 & 1.4 & 66.1 \\
Carbides [A - Fig. 8b] & 9.2 & 2.4 & 68.7 & 0 & 0.2 & 2.1 & 19.8 \\
White precipitates [B - Fig. 8b] & & 4.7 & 32.0 & 4.5 & 3.5 & 4.5 & 50.2 \\
New carbides [C - Fig. 8b] & & 3.0 & 55.8 & 0.4 & 1.5 & 3.2 & 33.9 \\
\hline
\end{tabular}




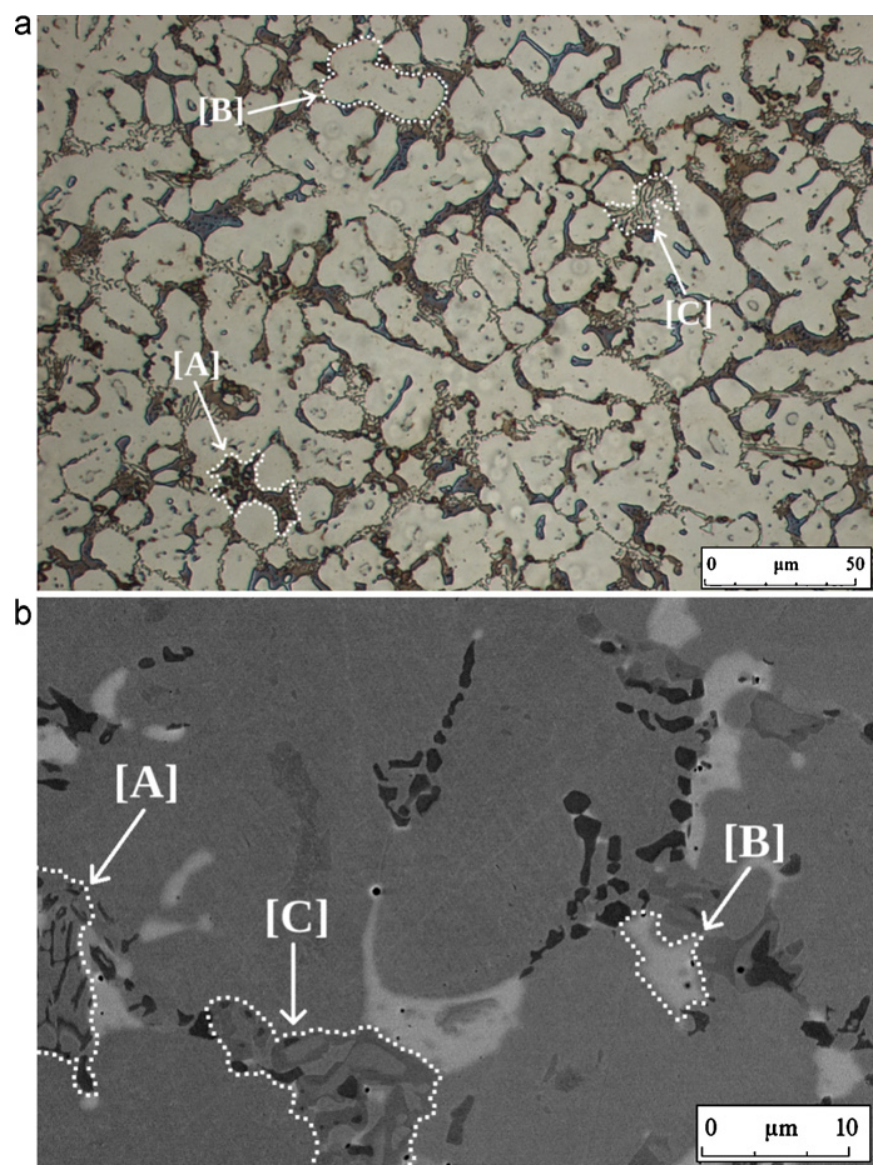

Fig. 8. R1100_SHORT sample microstructure - (a) optical microscopy and (b) SEM.

Table 7

R1100_LONG sample microprobe analysis - average phases composition (wt.\%).

\begin{tabular}{llllllll}
\hline & $\mathrm{C}$ & $\mathrm{Mn}$ & $\mathrm{Cr}$ & $\mathrm{Si}$ & $\mathrm{Ni}$ & $\mathrm{Mo}$ & $\mathrm{Fe}$ \\
\hline Austenite & 1.1 & 4.2 & 19.9 & 4.3 & 4.8 & 1.0 & 67.1 \\
Carbides & 6.2 & 3.0 & 59.5 & 0.1 & 1.0 & 3.7 & 28.7 \\
\hline
\end{tabular}

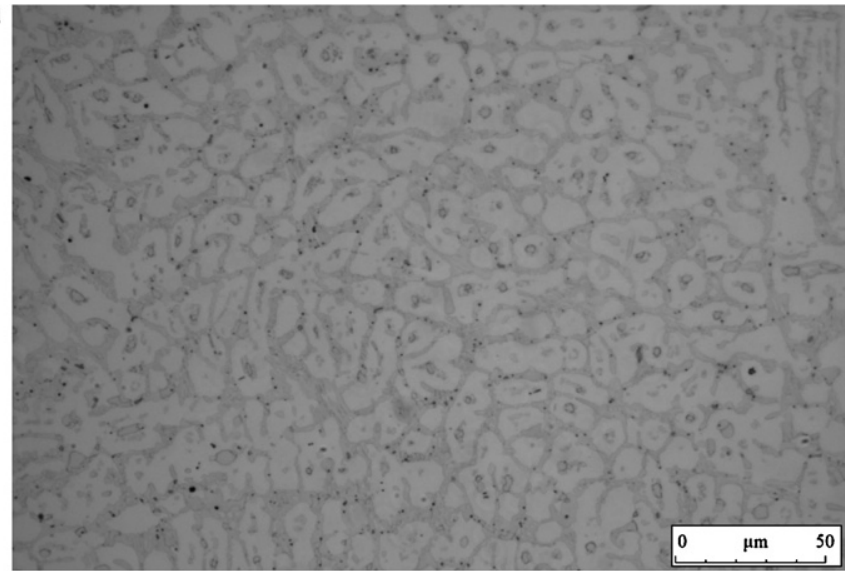

b

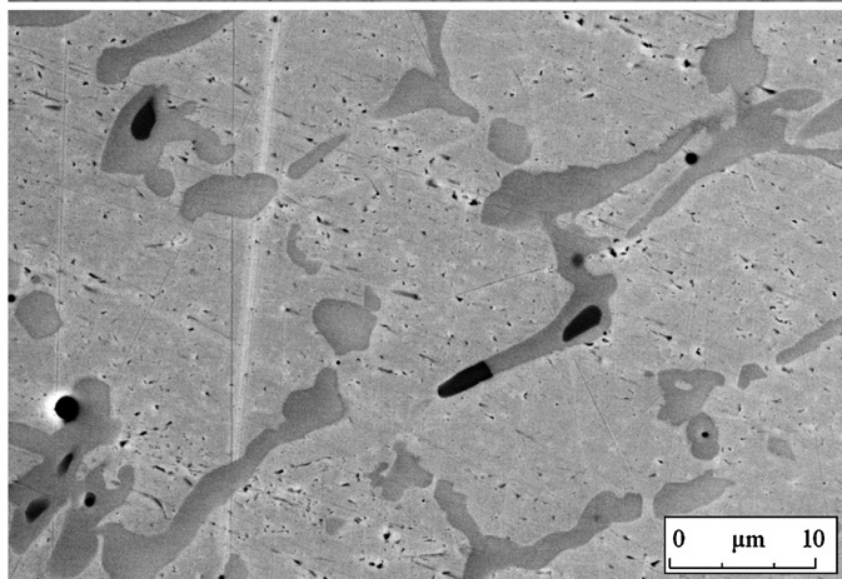

Fig. 9. R1100_LONG sample microstructure - (a) optical microscopy and (b) SEM.

Some $\mathrm{M}_{7} \mathrm{C}_{3}$ carbides can be observed, but both size and number decreased. Interdendritic zone consists in carbides with block morphology.

Specimen thermal gradient during heating phase also allows observation of material treated $2 \mathrm{~h}$ at $991^{\circ} \mathrm{C}$ and $938^{\circ} \mathrm{C}$. From the results it was observed that between $938^{\circ} \mathrm{C}$ and $991^{\circ} \mathrm{C}$, changes in microstructure are insignificant in comparison to as-deposit material.

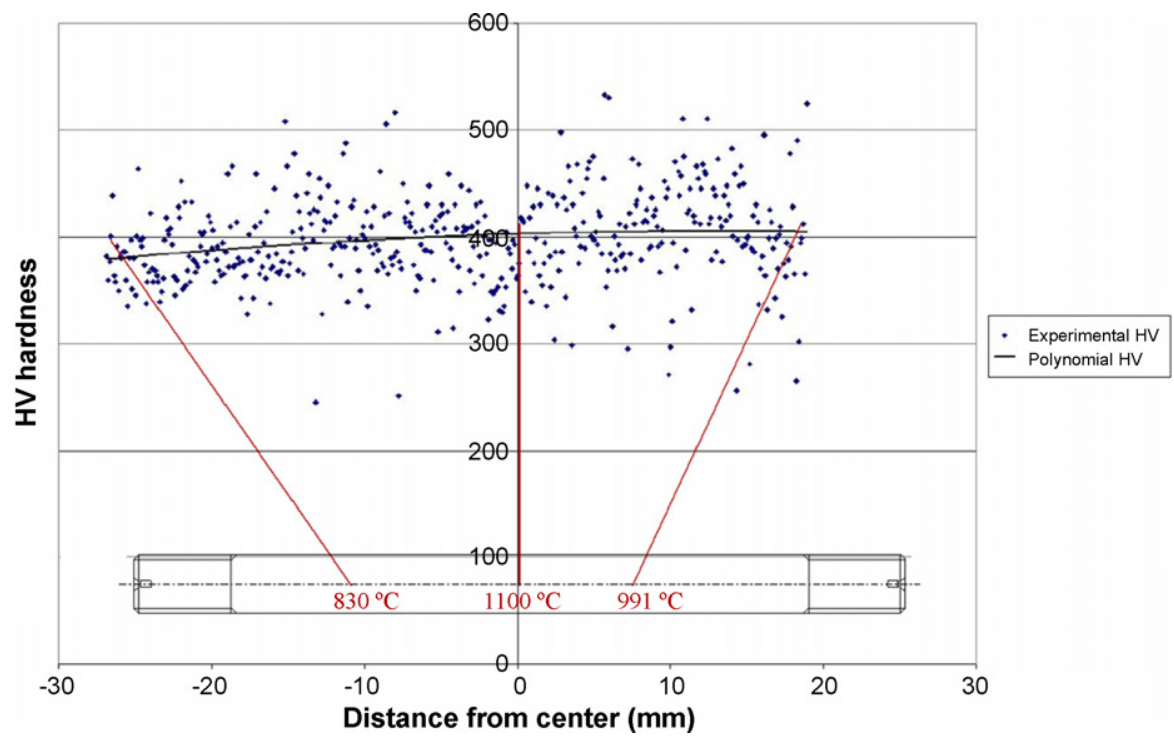

Fig. 10. Hardness profile taken across the cross section of R1100_LONG sample. 


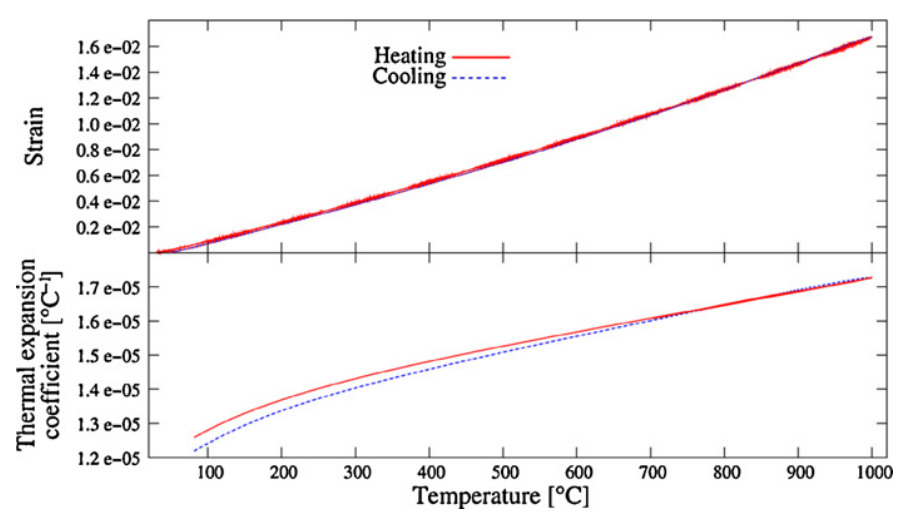

Fig. 11. Dilatation and thermal expansion coefficient along the longitudinal axis with temperature during heating and cooling.

Hardness profile taken along the longitudinal section of the R1100_LONG sample is presented in Fig. 10. It shows no significant evolution of hardness with temperature increase, Vicker's hardness being approximately $400 \mathrm{Hv}$. Moreover, these values are very close to as-deposit material value $(429 \mathrm{Hv})$ [12].

\subsection{Dilatometry tests}

Strain in the gauge length was measured during heating and cooling processes. Fig. 11 represents strain and thermal expan- sion coefficient as a function of temperature. Fig. 11 shows that there is essentially no brutal slope change in the temperature interval. There is a slight difference between thermal expansion during heating and cooling, mainly at high temperature, which could be explained by a difference between heating and cooling rates although it was not possible to distinguish them from measurements discrepancies. Slight differences in thermal expansion coefficient curve slope were observed for low temperature under $200^{\circ} \mathrm{C}$. After cooling, the length of the sample is restored. Dilatometry seems to indicate there is no relevant phase transformation detectable in the tested range of temperature.

\subsection{Tensile and cyclic tests}

True stress-strain curves at different temperatures are shown in Fig. 12. All curves are plotted until rupture of the specimen, excepted at $1000^{\circ} \mathrm{C}$, where elongation exceeded the extensometer measurement range due to high ductility at this temperature. It is worth noting that the strain scale in Fig. 12b is truncated to highlight the behaviour at low temperature. Elastic modulus $E$, yield stress $\sigma_{\mathrm{y}_{0.2}}$ and ultimate tensile stress were determined according to the norm NF-EN10002 [10] and are recapitulated in Table 5 as well as in Fig. 13.

The Young's modulus is found moderate at round temperature, slightly smaller than the one of 316L austenitic steel. The corresponding yield strength is found very high, whereas the ductility is very low $(A=1.36 \%)$, so was hard hardening rate $\left(R_{\mathrm{m}} / R_{\mathrm{p}_{0.2}} \approx 1.4\right)$. It is found that at constant strain rate $\left(10^{-4} \mathrm{~s}^{-1}\right)$ the Young's modulus and the yield strength decrease while ductility increases when rising test temperature.

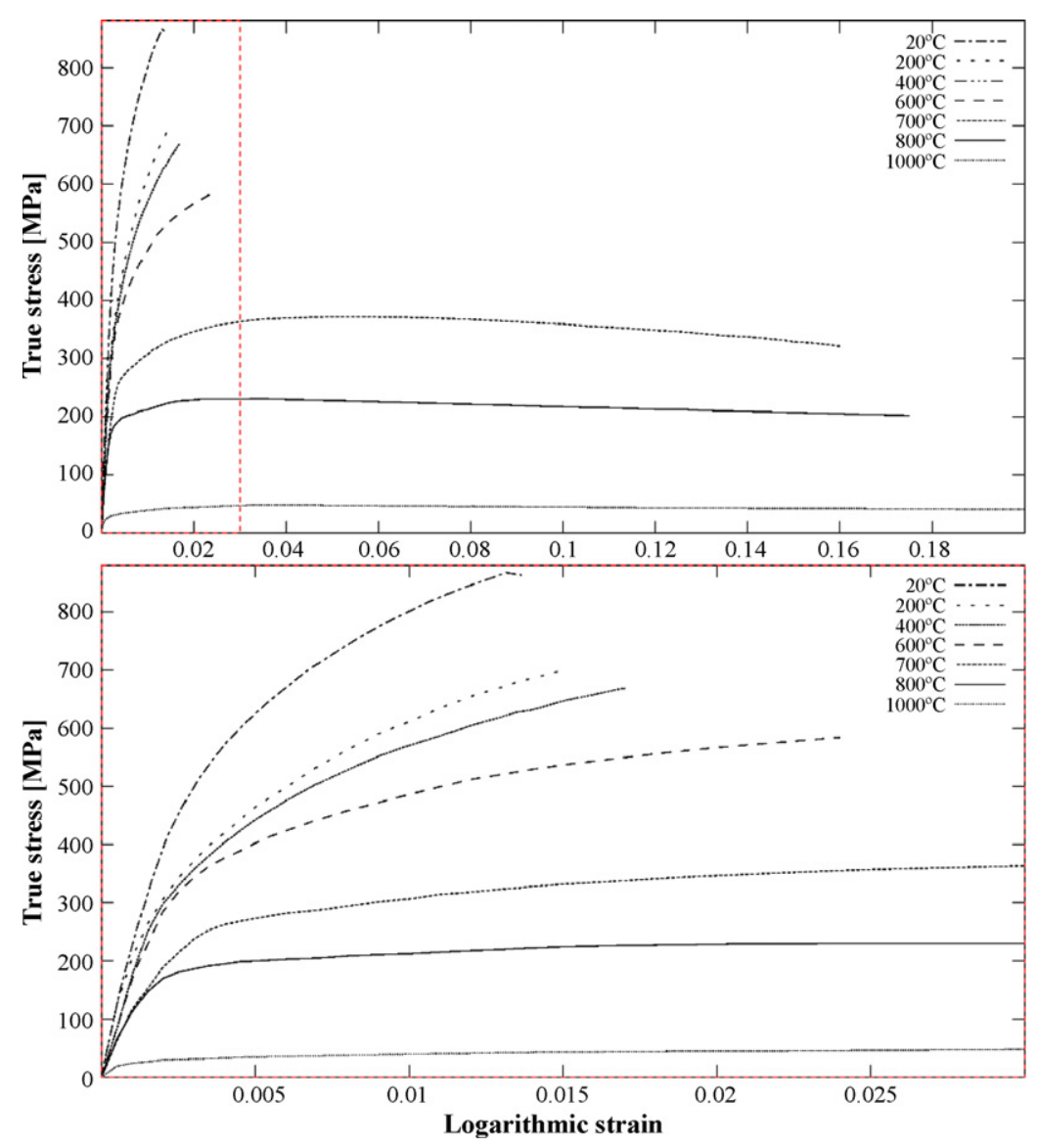

Fig. 12. True stress-strain curves for Norem 02 from $20^{\circ} \mathrm{C}$ up to $1000^{\circ} \mathrm{C}$. 


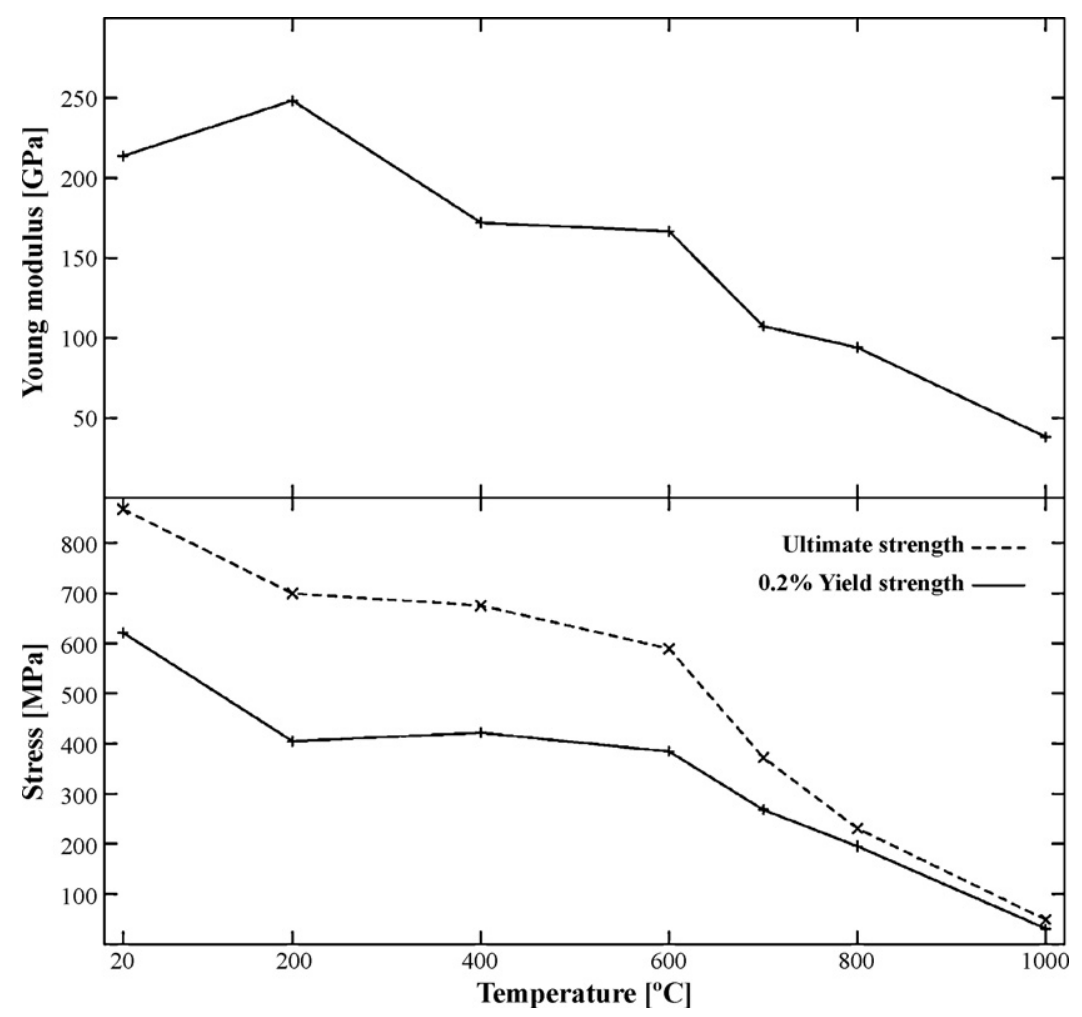

Fig. 13. Mechanical properties of Norem02. Young's modulus, ultimate strength and $0.2 \%$ yield strength versus temperature up to $1000{ }^{\circ} \mathrm{C}$.

Furthermore, the elastic modulus, the $0.2 \%$ yield strength, and the ultimate tensile strength show a moderately decreasing trend when the temperature rises from the room temperature to $600^{\circ} \mathrm{C}$. Above this temperature, the decrease is more significant.

The result of a cyclic test at room temperature is presented in Fig. 14. One can see that despite the low strain rate chosen $\left(10^{-4} \mathrm{~s}^{-1}\right)$, elongation at break was $0.85 \%$, far smaller than elongation at break during tension test at the same temperature (1.36\%). This result also exhibits a kinematic rather than isotropic hardening behaviour.

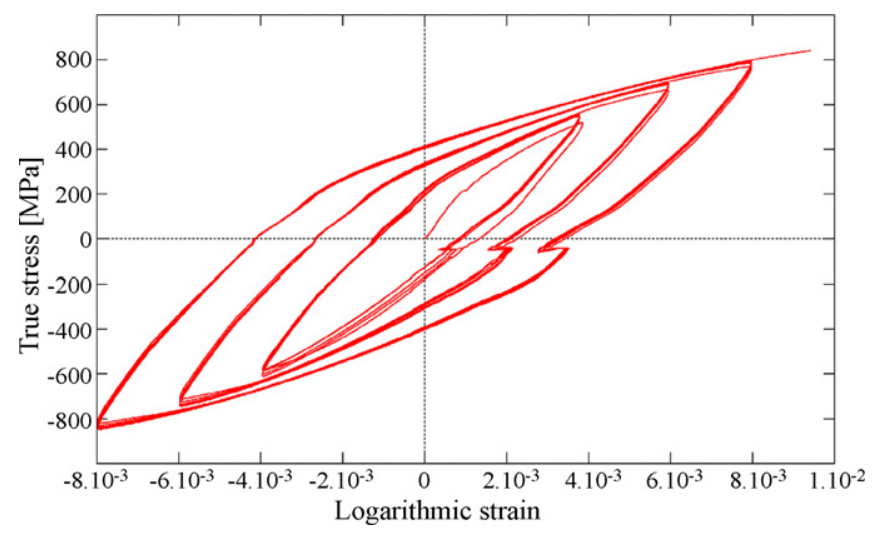

Fig. 14. Tension-compression curve for Norem 02 at $20^{\circ} \mathrm{C}-5$ cycles for each deformation rate.

\section{Discussion}

Some investigations by Ocken $[13,14]$ and Ohriner et al. [15] reported that the Norem02 microstructure is a solid-solution strengthened austenitic matrix with a continuous matrix with a continuous network of eutectic $\mathrm{M}_{7} \mathrm{C}_{3}$ and non-eutectic $\left(\mathrm{M}_{6} \mathrm{C}\right.$ and $\mathrm{M}_{3} \mathrm{C}$ ) carbides at the grain boundaries. This was later confirmed by Cockeram [2] and Miloudi [11] and their results are consistent with those presented in the present article.

The only slight differences in observed microstructure are induced, according to [15], by the deposition method, since the welding energy is far higher in PTAW than in other main welding processes.

Evolution of phase repartition was found qualitatively negligible for R1100_SHORT, and for parts of R1100_LONG specimen that were submitted to lower temperatures. This indicates that only a long reheating at high temperature is likely to provoke such changes, and that this should not be the case during multi-pass PTAW.

Moreover, Fig. 15 indicates that austenite composition remains nearly unchanged for R1100_SHORT and for R1100_LONG. A slight increase of the Fe proportion is noticed, probably indicating a change in the phase constitution. Due to diffusion, the austenite phase, growing to the detriment of ferrite becomes impoverished in Cr. Even with such changes in microstructure, no relevant discrepancy was observed in Vickers hardness values, indicating comparable mechanical properties for the altered microstructure.

Tensile and dilatometry tests exhibit no important evolutions in the Norem02 behaviour from ambient to $1000^{\circ} \mathrm{C}$. This clearly indicates that phase transitions or, taken as a whole, changes in microstructure, if there are any, are slight enough to be neglected in the modelling of the welding process. 


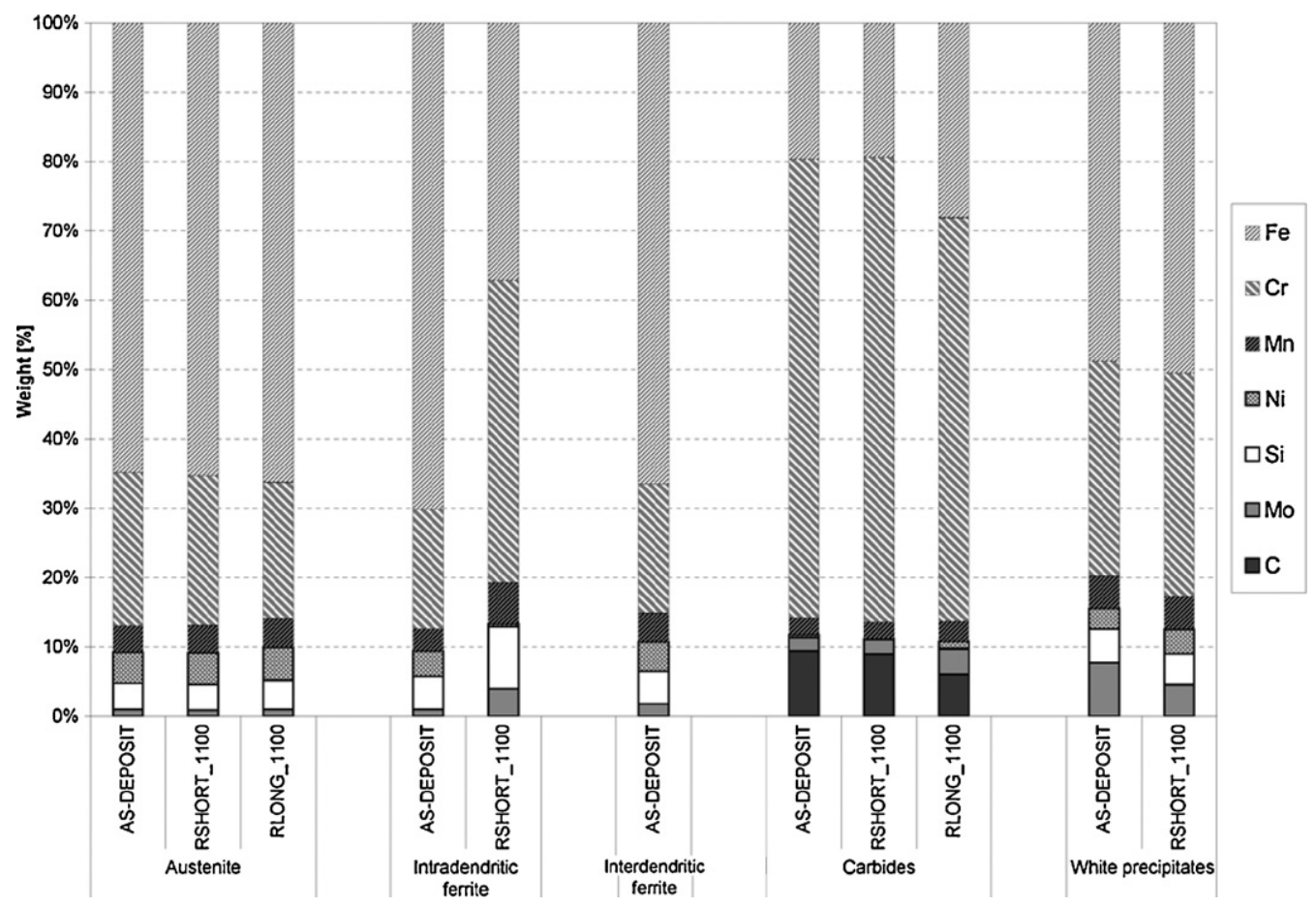

Fig. 15. Comparison of Norem02 microprobe analysis for observed specimen - average phase composition.

\section{Conclusion}

In this paper, PTAW-deposited Norem02 hardfacing coating was characterized, first by analysing its microstructure characteristics using several characterization means at as-deposit state, then by analysing them after undergoing a reheating thermal treatment representative of multi-pass welding. Norem02 can be mainly described as a continuous austenitic matrix presenting a dendritic morphology, with ferrite islets in the centre. Interdendritic region is constituted of $\mathrm{M}_{7} \mathrm{C}_{3}$ and austenite eutectic. Precipitate regions constituted with ferrite and network of carbides $\mathrm{M}_{23} \mathrm{C}_{6}$ have also been identified.

The evolution of microstructure has been understood as a function of holding time and temperature:

(i) At $1100^{\circ} \mathrm{C}$, a long time is needed to perturb the microstructure. However, the hardness remains almost unchanged.

(ii) Bellow $1100^{\circ} \mathrm{C}$, the microstructure is nearly not altered.

The dilatometry and tensile tests performed provide useful data to simulate Norem02 welding process and lead to the conclusions that:

(iii) Between room temperature and $1000^{\circ} \mathrm{C}$, no phase transformations are detected.

(iv) The Young's modulus, the $0.2 \%$ yield strength, and the ultimate tensile strength decrease moderately when the temperature increases from room temperature to $600^{\circ} \mathrm{C}$, and these trends are more pronounced above this temperature. Hardening at room temperature appears mainly as kinematic.

Further work will imply cyclic behaviour characterization, and use of those results in residual stress evaluation by finite element modelling for simplified geometries representing hard-faced valves parts [16].

\section{Acknowledgements}

This work was performed within EDF R\&D and INSA-Lyon LaMCoS laboratories, and was financed by EDF R\&D within the NICODEME 2 project. The authors would like to thank Joëlle Chesne and Philippe Chaudet for the support with experiments.

\section{References}

[1] V. Viswanathan, T. Laha, K. Balani, A. Agarwal, S. Seal, Materials Science and Engineering: R 54 (5-6) (2006) 121-285, doi:10.1016/j.mser.2006.11.002.

2] B.V.Cockeram, Metallurgical and Materials Transactions 33 (2002) 3403-3419.

[3] M.S. Yim, H. Ocken, Progress in Nuclear Energy 39 (1) (2001) 31-51.

[4] H. Ocken, Surface and Coatings Technology 76-77 (Part 2) (1995) 456-461.

[5] D.H.E. Persson, S. Jacobson, S. Hogmark, Wear 255 (2003) 498-503.

[6] J.-P. Mathieu, J.-F. Rit, J. Ferrari, D. Hersant, Proceedings of the ASME Pressure Vessel and Piping Conference, Bellevue (WA), USA, 2010 (paper ref. PVP201025721).

[7] D.J. Smith, S.J. Garwood, International Journal of Pressure Vessels and Piping 41 (3) (1990) 255-296.

[8] P. Duranton, J. Devaux, V. Robin, P. Gilles, J.M. Bergheau, Journal of Materials Processing Technology 153-154 (2004) 457-463.

[9] J. Dutheil, Construction Métallique 2 (1966)

[10] Method of testing at elevated temperature, European norme NF EN 10002-5, AFNOR, 1992

[11] S. Miloudi, Caractérisation métallurgique et mécanique du matériau de revêtement dur base fer NOREM 02 déposé par PTA, Note technique 05/0742, D4507, EDF UTO, 2005

[12] J. Chesne, Caractérisation des revêtements durs Norem02 élaborés par procédé PTA, Note technique H-T24-2010-02677-FR, EDF R\&D, 2010.

[13] H. Ocken, Advanced Materials and Processes 157 (2000) 103-104.

[14] H. Ocken, Performance of Norem Hardfacing Alloys, EPRI, Pao Alto, TR-1129931999.

[15] E.K. Ohriner, T. Wada, E.P. Whelan, H. Ocken, Metallurgical and Materials Transactions 22 (1991) 983-991.

[16] J.-P. Mathieu, F. Arnoldi, E. Gauthier, G. Beaurin, Proceedings of Fontevraud 7 Conference (paper A131 T07, 201). 